\title{
AN ISLAMIC SPIRITUAL ALTERNATIVE TO ADDICTION TREATMENT AND RECOVERY
}

\author{
Benaouda Bensaid*; Salah ben Tahar Machouche**; Mustafa \\ Tekke*** \\ *Istanbul Sabahattin Zaim University, Turkey; ${ }^{* *}$ International Islamic \\ University Malaysia; ***Düzce University, Turkey \\ email:benaouda.bensaid@izu.edu.tr
}

\section{Abstract}

The Islamic spirituality permeating the practice of Muslim religious beliefs, values, and norms, is positioned to play a pivotal role in addiction prevention, treatment, rehabilitation therapy and recovery of Muslim addicts. This study seeks to explore potential interconnections between spirituality, addiction treatments, recovery, and the ways and means with which Islamic spirituality may assist addicts in coping with inner urges, relapse, and recovery. This study seeks to lay the groundwork for future theoretical and empirical research on spirituality and addiction, development of spirituality-based addiction programs, and the assessment of related current spiritual philosophies, methods, and strategies. This inquiry discusses spirituality as a source of meaning-making and purpose cultivation, self-discipline, motivation, support, reintegration, and related issues arising in these regards, and highlights the need for utilizing spirituality as a critical instrument in addiction treatment programs. Islamic spirituality however is neither - and should not be considered - a sole treatment scheme, nor does it appreciate absolute reliance on non-spiritual means of recovery in favor of positivistic empirical methods.

[Spiritualitas Islam meresap ke pelbagai praktik keberagamaan, nilai dan norma, yang mana hal ini juga berperan penting pada pencegahan, pengobatan, terapi dan pemulihan kecanduan pada umat muslim. Artikel ini mengeksplorasi potensi keterkaitan antara spiritualitas, penyembuban 
Benaouda Bensaid et al.

kecanduan, pemuliban dan cara serta sarana spiritualitas Islam dalam membantu pecandu mengelola kondisi batin, ketika kambub dan pemulihan. Studi ini berusaba meletakkan dasar bagi penelitian teoretis dan empiris dimasa depan tentang spiritualitas dan kecanduan, pengembangan program kecanduan berbasis spiritualitas, dan penilaian filosofi, metode, dan strategi spiritual terkait. Artikel ini membahas spiritualitas sebagai sumber pembentukan makna dan penggalian tujuan, disiplin diri, motivasi, dukungan, reintegrasi, dan isu-isu terkait yang timbul dalam hal ini, dan menyoroti kebutuban untuk memanfaatkan spiritualitas sebagai instrumen penting dalam program perawatan kecanduan. Spiritualitas Islam bagaimanapun juga bukan-dan tidak boleh dianggap-satu-satunya skema pengobatan, tapi juga tidak tergantung mutlak pada sarana pemuliban non-spiritual yang menduk.ung metode empiris positivistik.]

Keywords: Muslim spirituality, Muslim addicts, recovery, treatment, management

\section{A. Introduction}

Across regional and national contexts, poor reproductive health, substance addiction, technological dependence, and mental health continue to threaten the wellbeing and futures of youth in Muslim societies ${ }^{1}$. According to a statement made by the Organization of Islamic Organization in 2017, wellbeing and sustaining healthy development is of seemingly grave concern when considering estimates by the UN Population Prospects of Muslim youth populations amassing to onethird of the world's future young population. Looming development and health concerns in the Muslim youth context has prompted concern of individuals and nations across the world. At the forefront of troubling issues faced by youth emerges from addictive behaviour, which leads to compulsive involvement in undesired behaviour at odds with the Islamic way of life. According to Jawad Fatayer, the repercussions of these addictions can be categorized into impacts on physical health (e.g., food and drinks), bodily functions to mind functions (e.g., alcohol and

1 Hisham Abu Raiya et al., "A Psychological Measure of Islamic Religiousness: Development and Evidence for Reliability and Validity", The International Journal for the Psychology of Religion, vol. 18, no. 4 (2008), pp. 291-315. 
narcotics), mind functions (e.g., gambling and computer), and mind and body (e.g., substance and caffeine) ${ }^{2}$

Among those, substance addiction, composed of mind and body integration, is referred to as alcohol, tobacco products, caffeine, prescription drugs, and drugs. These substances cause deterioration of health and lead to increase of addicts and additions. Many different factors cause the prevailing substance abuse. Limited availability of mental health services, parents uninformed on the needs of youth, increasing numbers of conflicts, and rising unemployment are elements intensifying pressure on youth mental health in Muslim societies; in turn leading to increased numbers of youth engaged in substance abuse and suffering addiction. ${ }^{3}$ There exists a plenitude of studies on addiction, spirituality, and recovery in the West, however little research focuses on Muslim groups by looking at the association between addiction recovery and spirituality. Attention to current research gaps on substance abuse research among Muslim populations will reduce the public health and medical burden of the issue in Muslim populations. ${ }^{4}$ There exists a great need for research on the accomplishments and failures of tailored treatment approaches for evaluation, given that ineffectual training may inadvertently increase stigma and create additional barriers to treatment. ${ }^{5}$ It is in consideration of this need that this study seeks to lay the groundwork for future theoretical and empirical research on spirituality and addiction, development of spirituality-based addiction programs, and the assessment of related current spiritual philosophies, methods, and strategies. This inquiry explores spirituality as a source of meaningmaking alongside self-discipline, motivation, support, and reintegration.

The concept of spirituality is of great concern to practitioners and researchers in the field as it has been known to be positively associated

2 Jawad Fatayer, "Addiction Types: A Clinical Sociology Perspective", Journal of Applied Social Science, vol. 2, no. 1 (2008), pp. 88-93.

3 SESRIC \& ICYF-DC, State of Youth in OIC Member States 2017 (Ankara: SESRIC-Statistical, Economic and Social Research and Training Centre for Islamic Countries, 2017), p. 35.

4 Ibid., p. $19 .$.

${ }^{5}$ Cynthia.L. Arfken and Sameera Ahmed, "Ten years of substance use research in Muslim populations: Where do we go from here?", Journal of Muslim Mental Health, vol. 10, no. 1 (2016), pp. 20-1. 
with physical health, emotional adjustment ${ }^{6}$ and often regarded in medical settings. ${ }^{7}$ To date, spirituality in Islam is viewed as the believer's relationship ${ }^{8}$ and closeness to God. ${ }^{9}$ The utilization of spirituality in addiction treatment, however, requires close attention to a patient's beliefs, behaviors and values in a manner that would allow for the effective understanding unique personal histories, mental states, and spiritual struggles. This study presents a Muslim spiritual alternative to treatment and recovery. We draw on primary and secondary sources, including the works of Muslim scholars on purification of the self, and Muslim physicians insisting on an integration of spirituality and medicine in the treatment of ailments. In the following, we discuss the crossroads between spirituality and addiction recovery, beginning first with definitions of each.

\section{B. Muslim Spirituality}

Spirituality is defined as a construct that provides meaning, purpose in life and a sense of personal identity. Most definitions of spirituality emphasize integrating connectedness with the transcendent which is broadly viewed as the natural world, God, the divine, or community. ${ }^{10}$ For some, "spirituality means many things to many minds and is undeniably a term that is used in varying contexts with different shades of meanings. Many have used this term to designate a special mark of spiritual disposition, and others have employed it to mark off a higher and final

${ }^{6}$ Kevin D. Jordan et al., "An Interpersonal Approach to Religiousness and Spirituality: Implications for Health and Well-being", Journal of Personality, vol. 82, no. 5 (2014), p. 418.

7 Peterman Ah et al., "Measuring Spiritual Well-Being in People with Cancer: the Functional Assessment of Chronic Illness Therapy-Spiritual Well-being Scale (FACIT-Sp)", Annals of Behavioral Medicine: a Publication of the Society of Behavioral Medicine, vol. 24, no. 1 (2002), p. 50.

8 Bagher; Miner Ghobary Bonab, "Attachment to God in Islamic Spirituality", Journal of Muslim Mental Health, vol. 7, no. 2 (2013), p. 78.

9 Mustafa Tekke and P.J. Watson, "Supplication and the Muslim Personality: Psychological Nature and Functions of Prayer as Interpreted by Said Nursi”, Mental Health, Religion \& Culture, vol. 20, no. 2 (2017), pp. 144-5.

${ }^{10}$ Elisabeth Gedge and Deirdre Querney, “The Silent Dimension: Speaking of Spirituality in Addictions Treatment", Journal of Social Work Values and Ethics, vol. 11, no. 2 (2014), p. 42. 
development of life itself". ${ }^{11}$ Spirituality is a multifaceted construct ${ }^{12}$ which has been identified as a crucial protective factor in the process of addiction recovery. ${ }^{13}$ Muslim spirituality goes hand in hand with its own worldview, knowledge, law, and ethics, education, purification, and self-discipline. Spirituality denotes the human experience imbued in the submission to the divine, and embraces knowledge of God and the world, worship, morality, lifestyle, and beneficence to others.

According to the Islamic tradition, the heart (qalb) is the central "locus" of human spirituality, and like physical organs can be healthy or damaged. Health, whether negative or positive, affects the quality of human emotions, thinking, and attitude. Muslims are exhorted to protect their faith, promote life, maintain property, and state of mind as axiomatic principles. They must protect their mind from any substance that could affect it to maintain the proper condition for the remembrance of Allah and prayers. ${ }^{14}$ Muslim spirituality is also associated with terms of self-purification such as belief, piety, righteousness, repentance, return to God, love of and fear from God, and excellence. The word "tarkiyab" meaning purification (Qur'an, 3: 164) is a key concept in the discipline of spirituality and is viewed as the surest path to the tranquil soul (al-nafs al-mutma'innah) following spiritual work on the self-critic soul (al-naf allawwämah). All wrongdoings are caused by sins, pushed by another side of the soul (al-nafs al-ammärah).

While the Qur'an places special focus on fundamental problems of belief and disbelief, it also draws serious attention to societal dilemmas including injustice, corruption, addictions, and so forth. The Qur'anic approach to moral problems is also gradual as shown in the case with

11 Allahbakhsh K. Brohi, “The Spiritual Significance of the Quran”, in Islamic Spirituality: Foundations, ed. by Seyyed Hossein Nasr (New York: Routledge, 2013), p. 67.

12 Helen Dermatis and Marc Galanter, "The Role of Twelve-Step-Related Spirituality in Addiction Recovery", Journal of Religion and Health, vol. 55, no. 2 (2016), p. 510 .

13 Audrey Hang Hai et al., "The Efficacy of Spiritual/Religious Interventions for Substance Use Problems: A Systematic Review and Meta-Analysis of Randomized Controlled Trials', Drug and Alcohol Dependence, vol. 202 (2019), p. 144.

${ }^{14}$ Mohamed Mahmood Nazar and Marican Sabitha, 'Incorporating Islam in the Therapeutic Community Modality for Rehabilitation of Substance and Drug Users. A Malaysian Experience", International Journal of Human and Health Sciences (IJHHS), vol. 1, no. 1 (2017), p. 11. 
alcohol consecutive prohibition stages. It first provides an overall assessment of wine consumption while contrasting its benefits and harms (Qur'an, 2: 219). At that moment of revelation, it is reported that some of the Prophet's companions gave up drinking, others however did not. Another verse followed which restricted only the time of consumption by prohibiting Muslims from consuming alcohol during prayers. This helped change the drinking habits of those who chose to continue drinking and opted to delay drinking up until after evening prayer. Finally, the verse of total prohibition of intoxicants was sent down. The Qur'an also advocates self-purification as leading to success. The Quran states: "He is indeed prosperous who has grown it in purity-away from selfaggrandizing rebellion against God" (Qur'an, 91: 9). Likewise, prophets and messengers are reported to have recommended purification from all sins and uncleanness (Qur'an, 2: 164).

The Islamic concept of good health and life (bayat tayyibab) also integrates spirituality. The Qur'an introduces the concept of 'good life' (Qur'an, 16: 97) and healing-wellness (shifä). The Qur'an (9: 14, 26: 80) describes itself as a source of healing (Qur'an, 17: 82), refers to God as "The Healer" (al-Shafă). For Shīrāzì (d. 925 AD), the Qur'an provides a set of curing remedies which when combined, cure the diseases of the heart (spiritual sickness). ${ }^{15} \mathrm{Ibn}$ al-Qayyim noted that the Qur'an is a healing of both spiritual and physical diseases and that spiritual diseases are caused by holding false beliefs and committing defamatory ethics. ${ }^{16}$ Scholarly works known as "al-tibb al-rubi or al-rubina" (Spiritual healing/medicine) seek to reform the soul's character and habits points to the present interest of Muslims physicians in the spiritual treatment of diseases. ${ }^{17}$ The Qur'anic view of diseases and illness relates to the 'spiritual' (heart) and body (jism). In his introduction to the "Medicine of the Prophet", al-Rāzì makes the following remarks:

"It is an imperative for every Muslim to draw nearer to God through the offering of righteous deeds, making utmost effort to discharge the

${ }^{15}$ Ṣadr al-Dīn Muhammad ibn Ibrāhīm Shīrāzī, Mafatih al-ghayb, vol. 17 (Beirut: Mu’assasat al-Tārīkh al-'Arabī lil-Ṭibā'ah wa-al-Nashr wa-al-Ṭawzī' , 1981), p. 121.

16 Al-Imam Ibn Qayyim al-Jawziyyah, Kitab Ar-Ruh, vol. 4, ed. by Muhammad Ajmal Ayub al-Islahi (Jeddah: Dar 'Alam al-Fawa'id, 2011), p. 10.

${ }_{17}$ Fakhruddin Ar-Razi, At-Thibb Ar-Rubani (Cairo: Maktabat al-Nahda alMisriyya, 1978), pp. 51-2. 
divine commands, and showing full obedience. The most effective way leading for that following observing the divine commands and abstinence of prohibitions is what benefits human to keep their health, cure their diseases for seeking the good health is prayers and supplications and acts of worship." 18

One basic goal of Islamic spirituality is to purify the self and strengthen the inner will, resilience and self-control of the addict. Spirituality is essentially preventive and helps, depending on the commitment of the spiritualist, develop levels of immunity and resilience against addictions and prevention against drug lapses. In his "al-tibb alRubin $\vec{a}$ ', Razi based his discussion of different addictions on the principle of desire subjugation, and their subjection to rational wisdom, which is the most noble and effective tool to reform the character of the soul. The Islamic tradition recommends the use of preventive and protective measures against diseases, whether spiritual, mental, or physical. Prophetic Muhammad is reported to have used ruqya, which is made of recited Qur'an with the aim of protection or cure for different types of illness. ${ }^{19}$

\section{Addiction Recovery}

Addiction is defined as a chronic, relapsing disorder characterized by compulsive drug seeking and use despite adverse consequences. ${ }^{20}$ Addiction recovery is a social medical process of realigning and redeveloping the substance user to achieve his functional life. It is also considered a brain disorder, as it involves functional changes to brain circuits involved in reward, stress, and self-control, and those changes may last a long time after a person has stopped taking drugs. ${ }^{21}$ Addiction is a lot like other diseases, such as heart disease. Both disrupt the normal, healthy functioning of an organ in the body, have serious harmful effects, and are, in many cases, preventable and treatable. However, if left untreated,

18 Muhammad ibn Aḥmad Dhahabī, al-Ṭibb al-Nabawi, 3rd edition, ed. by Ahmad Rif'at al-Badrawi (Beirut: Dar Ihya al-'Ulum, 1990), p. 18.

${ }_{19}$ Imam Muhammad bin Ismail bin al-Mughirah al-Bukhari, Sabih Al-Bukhari (Beirut: Dar Ibn Kathir, 2002), p. 544.

${ }^{20}$ National Institute on Drug Abuse, Drugs, Brains, and Behavior: The Science of Addiction (Maryland: U.S. Department Of Health And Human Services, 2007), p. 4.

${ }^{21}$ Ibid. 
they can last a lifetime and may lead to death. ${ }^{22}$

The American Psychiatric Association sees the recovery process as encouraging individuals to have hope and inclined to lead a meaningful life along with treatment interventions that best suit individuals' cultural, spiritual, and personal ideals. ${ }^{23}$ The concept of recovery has been associated with a return to health after trauma or illness. ${ }^{24}$ and has been defined as the process of facilitating patients to achieve their health and well-being. ${ }^{25}$ Recovery involves the use of internal and external resources to voluntarily resolve addiction problems and consciously develop a healthy, productive, and meaningful life. ${ }^{26}$

Substance use addiction is a serious public health problem and bears numerous negative health outcomes such as heart disease, ${ }^{27}$ cancer, premature mortality, chronic pain, hypertension, injuries, poisonings, overdoses, and infectious diseases. ${ }^{28}$ Substance abuse and addiction is a social problem that leads to the perception that substance users are morally weak. What most people fail to understand is addictionss complexity as substance use significantly changes the brain to encourage addiction. It is therefore, unlike commonly believed, not just a matter of willpower or mere abstinence. ${ }^{29}$

Factors of family life can increase a person's risk for substance abuse. Home environment, especially during formative years, is a vital

\section{Ibid.}

${ }^{23}$ Nady El-Guebaly, "The Meanings of Recovery from Addiction: Evolution and Promises", Journal of Addiction Medicine, vol. 6, no. 1 (2012), p. 2.

${ }^{24}$ William L. White MA, "Recovery: Its History and Renaissance as an Organizing Construct Concerning Alcohol and Other Drug Problems", Alcoholism Treatment Quarterly, vol. 23, no. 1 (2005), pp. 3-15.

${ }^{25}$ David Mee-Lee et al., Patient Placement Criteria for the Treatment of SubstanceRelated Disorders, Second Edition-Revised, (Chevy Chase, Maryland: Amer Society of Addiction Medicine, 2001).

${ }^{26}$ William L. White, "Addiction Recovery: Its Definition and Conceptual Boundaries", Journal of Substance Abuse Treatment, vol. 33, no. 3 (2007), p. 236.

${ }^{27}$ Sharlene Kaye et al., "Methamphetamine and Cardiovascular Pathology: a Review of the Evidence", Addiction, vol. 102, no. 8 (2007), p. 1208.

28 Amber L. Bahorik et al., "Alcohol, Cannabis, and Opioid Use Disorders, and Disease Burden in an Integrated Healthcare System", Journal of Addiction Medicine, vol. 11, no. 1 (2017), pp. 3-9.

${ }^{29}$ Carmen Berzinski, "Recovery Mentorship Programs and Recovery from Addiction”, Master Thesis (Minnesota: St. Catherine University, 2012). 
factor. Parents or role models who smoke, engage in substance abuse, or break the law, can increase children's risk of future drug problems. During teenagerhood, peers can have an increasingly strong influence and can sway even those without risk factors to experiment with drugs. Struggling in school or poor social skills are further risks for potential addictions. ${ }^{30}$ The social life of children and youth is significantly influenced by overall family religiosity and value-focused behaviors such as integrity, honesty, traditional values, and so forth.

The mental process of addiction utilizes the same pathways as the reward circuit that affects adaptive behavior and good decision making. Along with meditation and mindfulness training, psychosocial interventions, and pharmacologic approaches, there has been an increased literature on spirituality driven approaches as outlined in this article. Extensive and thorough understandings of chemical dependency and combined approaches to treatment can facilitate effective addiction treatment. ${ }^{31}$ The course of addiction recovery involves repeated attempts of abstinence supported by a range of therapeutic interventions, which must be adapted to each patient's substance abuse pattern to ensure sustained recovery. ${ }^{32}$

Positive psychology is associated with rigorous scientific study of individual strength, wellness, and optimal functioning. ${ }^{33}$ This approach in psychology seeks to promote the life satisfaction substance user populations as it is defined as an intervention, therapy, or activity intended to increase the positive feelings, behaviors, and cognitions unlike fixing the negative thoughts or maladaptive behavioral patterns. ${ }^{34}$ For instance, the success of such interventions was experimentally measured through

${ }^{30}$ National Institute on Drug Abuse, Drugs, Brains, and Behavior: The Science of Addiction, p. 8 .

31 Daniel H. Angres and Kathy Bettinardi-Angres, “The Disease of Addiction: Origins, Treatment, and Recovery”, Disease-a-Month: DM, vol. 54, no. 10 (2008), p. 696.

32 Berzinski, "Recovery Mentorship Programs and Recovery from Addiction", p. 14.

33 Angela Lee Duckworth, Tracy A. Steen, and Martin E.P. Seligman, "Positive Psychology in Clinical Practice”, Annual Review of Clinical Psychology, vol. 1 (2005), p. 630.

${ }^{34}$ Nancy L. Sin and Sonja Lyubomirsky, "Enhancing Well-Being and Alleviating Depressive Symptoms with Positive Psychology Interventions: a Practice-Friendly Meta-Analysis, Journal of Clinical Psychology, vol. 65, no. 5 (2009), p. 469. 
150 individuals who completed residential treatment in Chicago. ${ }^{35}$ The research findings reveal that individual residents had lower rates of substance use, lower rates of illegal activity, and higher employment rates. ${ }^{36}$

In recent years, social networks and group support have emerged as strong predictors of wellbeing. One study identified that networks which encouraged recovery were among the strongest predictors of drinking cessation. ${ }^{37}$ Gaining support from non-substance users can significantly influence recovery from drug use. ${ }^{38} \mathrm{~A}$ social identity approach facilitates the knowledge of the addiction process and recovery not only in terms of transitioning to health, but also in terms of being driven by social networks and identity change. ${ }^{39}$

Another approach in recovery addiction which has proven effective is the 12-step model developed by Narcotics Anonymous. The program offers support groups and numerous other services in addiction recovery. Although treatment comprise of cognitive behavioral, motivational, relapse prevention, and eclectic approaches, they mostly recommend the 12-step support group program to addicts. ${ }^{40}$ The favorable outcomes of the 12-step model have been favorably supported by numerous studies; substance users who attended 12-step meetings regularly showed higher levels of functioning and longer periods of sobriety as compared to those

${ }^{35}$ Leonard A. Jason et al., "Communal Housing Settings Enhance Substance Abuse Recovery", American Journal of Public Health, vol. 96, no. 10 (2006), p. 35.

${ }^{36}$ Leonard A. Jason and Joseph R. Ferrari, "Oxford House Recovery Homes: Characteristics and Effectiveness”, Psychological services, vol. 7, no. 2 (2010), p. 92.

37 Richard Longabaugh et al., "Network Support as a Prognostic Indicator of Drinking Outcomes: the Combine Study", Journal of Studies on Alcohol and Drugs, vol. 71, no. 6 (2010), pp. 837-46.

${ }^{38}$ David W. Best et al., "Breaking the Habit: A Retrospective Analysis of Desistance Factors Among Formerly Problematic Heroin Users", Drug and Alcohol Review, vol. 27, no. 6 (2008), p. 620.

${ }^{39}$ Ramez Bathish et al., "Is it Me or should my Friends Take the Credit?” The Role of Social Networks and Social Identity in Recovery from Addiction", Journal of Applied Social Psychology, vol. 47, no. 1 (2017), p. 36.

${ }^{40}$ John McKellar, Eric Stewart, and Keith Humphreys, "Alcoholics Anonymous Involvement and Positive Alcohol-Related Outcomes: Cause, Consequence, or Just a Correlate? A Prospective 2-year Study of 2,319 Alcohol-Dependent Men”, Journal of Consulting and Clinical Psychology, vol. 71, no. 2 (2003), p. 307. 
who did not. ${ }^{41}$ Moreover, a longitudinal study found that duration and intensity of the 12-step support group attendance significantly increased abstinence rates. ${ }^{42}$ In 2007, an Alcoholics Anonymous survey showed that almost half the number of participants reported being sober for 5 or more years and $33 \%$ reported being sober for over 10 years. ${ }^{43}$ Such support groups have proven promising in relapse prevention as they are accessible in communities, free of cost and can be attended at any time. ${ }^{44}$

There exist many related coping mechanisms such as emotional regulation, self-control, social engagement, and interpersonal relationships. These mechanisms present the potential of spiritual experiences and engagements which are helpful to realize the potentialities of inner urge. This is since spirituality infiltrates the inner human fabric and affects deep lying emotions, inner drives, orientation, and social interactions. Spirituality is essentially defined as the inner dynamic drive with his own or varying figures that will enable him to regulate emotions.

\section{Spirituality and Addiction Recovery}

Numerous studies have attempted to assess the relationship between addiction recovery and religion. In recent years, this attention and appreciation has seen increase with scientific literature discussing the role of spirituality in clinical practice and particularly within addiction

${ }^{41}$ Berzinski, "Recovery Mentorship Programs and Recovery from Addiction", pp. 3-4.

${ }^{42}$ Lee Ann Kaskutas et al., "Effectiveness of Making Alcoholics Anonymous Easier: a Group Format 12-Step Facilitation Approach", Journal of Substance Abuse Treatment, vol. 37 , no. 3 (2009), p. 9.

${ }^{43}$ Service Material from the General Service Office, "Estimated Worldwide A.A. Individual and Group Membership", Alcoholics Anonymous, https://www.aa.org/ assets/en_us/aa-literature/smf-132-estimates-worldwide-aa-individual-and-groupmembership, accessed 9 Jan 2021.

${ }^{44}$ Kelly Jf, Yeterian J, and Myers Mg, "Treatment Staff Referrals, Participation Expectations, and Perceived Benefits and Barriers to Adolescent Involvement in 12Step Groups', Alcoholism Treatment Quarterly, vol. 26, no. 4 (2008), pp. 427-49; Keith Humphreys and Rudolf H. Moos, "Encouraging Posttreatment Self-help Group Involvement to Reduce Demand for Continuing Care Services: Two-year Clinical and Utilization Outcomes", Alcoholism, Clinical and Experimental Research, vol. 31, no. 1 (2007), pp. 193-8. 
recovery. ${ }^{45}$ Empirical evidence in this field has shown that spirituality is the positive predictor of abstinence. ${ }^{46}$ Spiritual attendance, motivation, devotion, religious affiliations with proscriptions against alcohol, and existential well-being are factors that have been identified as being protective against substance use. ${ }^{47}$ Scientific studies also prove that variables of spirituality are associated with reduced levels of alcohol/ drug use. The inclusion of spirituality in the addiction recovery process is significantly important for patients to positively engage with recovery, coping, the experiences of psychosis, and in learning how to respond positively. ${ }^{48}$

The study of alcohol use disorders, personality, and spirituality shows that spirituality and alcoholism correlate with personality traits. ${ }^{49}$ Moreover, increased levels of spirituality significantly predict the improved substance use outcomes. ${ }^{50}$ Moreover, spiritual interventions proved more effective as compared to non-spiritual interventions for people with substance use problems. ${ }^{51}$ Moreover, approximately 147 research studies revealed that religion proved to be a strong deterrent to substance use among adolescents and young people. A significant correlation was found between engagement in religious practices and less

${ }^{45}$ Harold Koenig, Dana King, and Verna B. Carson, Handbook of Religion and Health (New York: Elsevier Science \& Technology, 1998), pp. 177-85.

${ }^{46}$ C. McMillen et al., "Positive by-Products of the Struggle with Chemical Dependency", Journal of Substance Abuse Treatment, vol. 20, no. 1 (2001), p. 77.

47 Tyrone F. Borders and Brenda M. Booth, "Stimulant Use Trajectories and the Longitudinal Risk of Heavy Drinking: Findings from a Rural Population-Based Study", Addictive Behaviors, vol. 37, no. 3 (2012), pp. 269-72.

${ }^{48}$ Christopher C.H. Cook, "Religion and Spirituality in Clinical Practice", BJPsych Advances, vol. 21, no. 1 (2015), pp. 46-7.

49 Jon Randolph Haber, Laura B. Koenig, and Theodore Jacob, "Alcoholism, Personality, and Religion/Spirituality: an Integrative Review", Current Drug Abuse Reviews, vol. 4, no. 4 (2011), pp. 250-60.

${ }^{50}$ Melissa L. Miller and Stephen M. Saunders, "A Naturalistic Study of the Associations between Changes in Alcohol Problems, Spiritual Functioning, and Psychiatric Symptoms", Psychology of Addictive Behaviors : Journal of the Society of Psychologists in Addictive Behaviors, vol. 25, no. 3 (2011), p. 455.

${ }^{51}$ Benita Walton-Moss, Ellen M. Ray, and Kathleen Woodruff, "Relationship of Spirituality or Religion to Recovery from Substance Abuse: A Systematic Review", Journal of Addictions Nursing, vol. 24, no. 4 (2013), p. 218. 
involvement in problematic social behaviors. ${ }^{52}$ Furthermore, substance use attitudes and lower rate of substance use are strongly affected by religious beliefs and practices ${ }^{53}$ this was especially true for individuals who regularly practice religious beliefs. ${ }^{54}$ For instance, 364 adults were recruited from two abstinence-based treatment centers and examined for changes in spirituality. Results over the six months follow up period revealed significant changes in spirituality including increased belief, private practices, spiritual experiences and self-forgiveness. ${ }^{55}$ However, 512 college students were studied to identify the mediator between spirituality and alcohol use which revealed several factors such as negative beliefs about alcohol, social influences, and spiritual wellbeing. ${ }^{56}$

The effects of spirituality throughout the addiction recovery process on of 12 consecutive months of abstinence revealed that due to existential well-being, the odds of continued abstinences significantly increased.$^{57}$ Numerous cross-sectional studies supported the fact that spirituality is associated with addiction recovery and higher spirituality levels are significantly associated with longer recoveries and reduced risks

${ }^{52}$ Mahmood Nazar Mohamed and Mohd Yunos Pathi Mohd, "The Role of Family in Preventing Drug Addiction", presented at the 2nd Asian Seminar on Family Support Group Network (Colombo, Sri Lanka, 3 May 2004); Mahmood Nazar Mohamed and S. Marican, 'Treatment and Rehabilitation of Substance Use Disorder: Significance of Islamic Input in Malaysia', International Journal of Human and Health Sciences (IJHHS), vol. 2, no. 4 (2018), pp. 209-16.

53 Sawitri Assanangkornchai, Katherine M. Conigrave, and John B. Saunders, "Religious Beliefs and Practice, and Alcohol Use in Thai Men", Alcohol and Alcoholism, vol. 37 , no. 2 (2002), p. 196.

${ }^{54}$ Mark J. Edlund et al., "Risks for Opioid Abuse and Dependence Among Recipients of Chronic Opioid Therapy: Results from the TROUP Study", Drug and Alcohol Dependence, vol. 112, nos. 1-2 (2010), pp. 90-8.

55 Elizabeth A.R. Robinson et al., "Six-Month Changes in Spirituality and Religiousness in Alcoholics Predict Drinking Outcomes at Nine Months", Journal of Studies on Alcohol and Drugs, vol. 72, no. 4 (2011), p. 664.

56 Thomas J. Johnson, Virgil L. Sheets, and Jean L. Kristeller, "Identifying Mediators of the Relationship between Religiousness/Spirituality and Alcohol Use", Journal of Studies on Alcohol and Drugs, vol. 69, no. 1 (2008), p. 160.

${ }^{57}$ Katherine M. Piderman et al., "Spirituality During Alcoholism Treatment and Continuous Abstinence for One Year", The International Journal of Psychiatry in Medicine, vol. 38 , no. 4 (2008), p. 395. 
of relapse. ${ }^{58} \mathrm{~A}$ study on AA members who achieved at least six months of abstinence have shown the significant change in multiple domains of spiritual functioning such as heightened God experiences, religious affiliation, mystical experiences, and appreciation of character values and aesthetics. ${ }^{59}$ Several research studies prove religious integration as a significant asset in addiction recovery ${ }^{60}$ while psycho-spiritual therapy proved effective in drug addiction treatment and recovery. The most common belief is that individuals involved in substance use do not possess strong spiritual beliefs therefore, religious therapy may be a beneficial treatment of recovery. ${ }^{61}$

Religious interventions are proven to be effective when individuals are treated as respected humans, supported by the group, and treated equally within a judgment free environment ${ }^{62}$ away from ostracization. Increase in religious practice translated into significantly improved outcomes. ${ }^{63}$ Another study conducted by Linda Haddad suggested that participants affirmed that religious organizations and mosques were excellent resources for seeking help, and that prayer often helped address substance use $\mathrm{e}^{64}$. Moreover, a study conducted in the USA revealed that

58 CADC Betty Jarusiewicz, "Spirituality and Addiction", Alcoholism Treatment Quarterly, vol. 18, no. 4 (2000), p. 107.

59 R.J. Mathew et al., "A Retrospective Study of the Concept of Spirituality as Understood by Recovering Individuals", Journal of Substance Abuse Treatment, vol. 13, no. 1 (1996), p. 69.

${ }^{60}$ John F. Kelly et al., "Spirituality in Recovery: A Lagged Mediational Analysis of Alcoholics Anonymous' Principal Theoretical Mechanism of Behavior Change", Alcoholism, Clinical and Experimental Research, vol. 35, no. 3 (2011), p. 455.

${ }^{61}$ Tahereh Seghatoleslam et al., "Achieving a Spiritual Therapy Standard for Drug Dependency in Malaysia, from an Islamic Perspective: Brief Review Article", Iranian Journal of Public Health, vol. 44, no. 1 (2015), p. 22; M.Z.M. Zohdi Amin et al., "A Literature Review of Spiritual Psychotherapy Using Quran Recitation in the Treatment of Drug Addiction", Advanced Science Letters, vol. 23, no. 5 (2017), p. 3.

${ }^{62}$ Zila van der Meer Sanchez and Solange Aparecida Nappo, "Religious Intervention and Recovery from Drug Addiction", Revista De Saude Publica, vol. 42, no. 2 (2008), p. 6.

${ }^{63}$ Robinson et al., "Six-Month Changes in Spirituality and Religiousness in Alcoholics Predict Drinking Outcomes at Nine Months", p. 667.

${ }^{64}$ Linda Haddad et al., "Knowledge of Substance Abuse Among High School Students in Jordan", Journal of Transcultural Nursing, vol. 21, no. 2 (2010), pp. 143-50. 
strong Islamic beliefs protected adolescents from substance abuse. ${ }^{65}$

\section{E. The Pursuit of A Muslim Spiritual Addiction Treatment and Recovery}

Numerous efforts have recently been made to integrate religious beliefs into addiction recovery treatments such as spiritual psychotherapy which have been proven effective in recovery and preventing relapse ${ }^{66}$ through a focus on repentance, remembrance, fasting, and prayers for curing individuals involved in substance abuse. ${ }^{67}$ In many Muslim majority countries, most social, behavioral, and correctional programs place significant emphasis on religious based rehabilitation. ${ }^{68}$ Millati Islami is one program which borrows and 'islamizes' the 12-Step spiritual Addiction Recovery program for Muslims with customizations to include aspects of acknowledging the neglected higher self, unmanageability of life, belief in Allah's power to restore sanity, submission to the will of Allah, fearless moral self-inventory, recognition of the exact nature of one's wrongs, willingly and openly seeking Allah's guidance change, prayer for forgiveness, resolve to make amends for harm done to others, prayer and perusal for deeper comprehension of love and reverence for Allah, regard for the ideal of ihsan, and sharing uplifting messages with others. Although this program is considered critical in achieving and maintaining sobriety, it is likely most successful when accompanied by other forms of therapy, counselling, and medicinal treatment. ${ }^{69}$

In the following, we discuss the various methods within addiction treatment and recovery designed to rejuvenate the addict in generating

${ }^{65}$ Lina Kurdahi Badr, Asma Taha, and Vivien Dee, "Substance Abuse in Middle Eastern Adolescents Living in Two Different Countries: Spiritual, Cultural, Family and Personal Factors", Journal of Religion and Health, vol. 53, no. 4 (2014), pp. 1060-74.

${ }^{66}$ Amin et al., "A Literature Review of Spiritual Psychotherapy Using Quran Recitation in the Treatment of Drug Addiction", p. 3.

${ }^{67}$ N.H.N. Muhammad et al., "Prevention of Addiction Based on Islamic Ways", International Journal of Academic Research in Business and Social Sciences, vol. 9, no. 2 (2019), p. 867.

${ }_{68}$ Mohamed and Marican, "Treatment and Rehabilitation of Substance Use Disorder", p. 213.

${ }^{69}$ Krystina Murray, "Muslim Drug and Alcohol Abuse Rehab", Addiction Center (18 Sep 2020), https://www.addictioncenter.com/treatment/faith-based-drug-andalcohol-rehab/muslim/, accessed 9 Oct 2020. 
self-control and garnering a deep awakening. This first involves the cultivation of meaning and purpose through education, learning and guidance. This is complemented by developing self-discipline through exercises of self-purification, practices of worship, engaging in rituals, and community integration. It is important to note that there is no single addiction treatment, therapy, or rehabilitation process, appropriate for all individuals, as each individual represents a unique background, experience, and evolving needs. Mansur posited that both models together should provide enough incentive for God-fearing and God-loving Muslims to refrain from substance use. However, neither are particularly helpful to those who already suffer addictions nor is such an approach instrumental in transforming attitudes towards addicts. For him, individuals seeking an escape from addictive disorders are better off relying on a practical model based on remorse and personal redemption. ${ }^{70}$

\section{Cultivation of Meaning and Purpose}

First the understanding of the principle of fitrah (innate human nature) is fundamental to all change and transformational processes. Fitrah refers to inner predispositions of perfection and uprightness of God's creation. ${ }^{71}$ The Islamic view of fitrab is embedded in all branches of knowledge and behavior, especially those related to diet, health, wellbeing, recovery, and life balance. Assumptions held about human nature are crucial to conceptualizing and operationalizing addiction recovery and fostering well-being. In the context of addiction treatment, conflicting elements of human nature include al-nafs al-'ammarah bil-sa', al-nafs allawwamah, and al-nafs al-mutma'innab in which triumph of the reproaching self over the evil self is sought. ${ }^{72}$ Control over this conflict of inner selves grows even more crucial in relation to the belief in a hereafter. Such a belief has the potential to drive for self-control, responsibility, and hope in divine justice. There is also the notion of purification of

${ }^{70}$ Mansur Ali, "Perspectives on Drug Addiction in Islamic History and Theology", Religions, vol. 5, no. 3 (2014), p. 68.

${ }^{71}$ Salah ben Tahar Machouche, Bensaid Benaouda, and Fadila Grine, "Positive Thinking: An Islamic Perspective", Al-Shajarah: Journal of the International Institute of Islamic Thought and Civilization, vol. 17, no. 2 (2012), p. 234.

72 Al-Imam Ibn Qayyim al-Jawziyyah, Kitab Ar-Ruh, vol. 2, ed. by Muhammad Ajmal Ayub al-Islahi (Jeddah: Dar'Alam al-Fawa'id, 2011), pp. 624-41. 
the spirit, Muslim spirituality thus represents a fundamental component in the Muslim quest for purpose and meaning in life. ${ }^{73}$

Psychotherapies, such as cognitive behavioral therapy or acceptance and commitment therapy look at thinking patterns and behaviors which maintain addictions and alter the individual's relationship with their thoughts. For Muslim addicts, a spiritual shift is required towards regaining a level self-reflection, awakening and realizations with regards to their condition and self. This, however, demands patience and calculated judgment, especially in defining causes, establishing appropriate individual measures, and moderately applying treatment. According to Ibn al-Qayyim, the treatment of addictions affecting the soul and body commence with probing the person's belief, eradicating ignorance, addressing doubts, and acknowledging experiences of loss or perplexity. The knowledge of the Creator, His names, attributes, manifestations, and commands and discipline of the heart which begin with drives addicts towards the pursuit of the divine love and pleasure, thus resulting in abstentions from prohibitions.

Islamic approach-based rehabilitation centers are known to assist their residents learn and memorize the five pillars of Islam with the belief that Islamic teachings may guide their future path, help identify their goals, and allow for meaningful investment of time and energy in the way of benefitting their present and afterlife. ${ }^{74}$ Several religious based addiction recovery programs focus on self-introspection, and include religious educational classes, studies of the Prophet Muhammad's life, reading the stories of his companions, and finding inspiration in the wisdom and courage of his successors (caliphs). This is achieved through religious programs, talks and assessments as to whether participants qualify for the following treatment phases. ${ }^{75}$ Through daily prayers, remembrance of the Divine, reflective meditations, thankfulness, and mindfulness, spirituality seeks to drive spiritualists to higher levels of the self. These new heights

${ }^{73}$ Benaouda Bensaid, "Crossroads Between Muslim Spirituality and Environmental Sustainability”, Journal of Al-Tamaddun, vol. 13, no. 1 (2018), p. 66.

${ }^{74}$ Mahmood Nazar Mohamed et al., "Validation of Addiction Severity Index (5th edition) Bahasa Melayu Version (ASI-5-BM)", MOJ Addiction Medicine \& Therapy, vol. 4, no. 2 (2017), pp. 243-7.

${ }^{75}$ Mohamed and Marican, "Treatment and Rehabilitation of Substance Use Disorder", p. 213. 
comprise of self-satisfaction, facilitated introspection, refined personal and moral character, as well as sustained bonds communal bonds of cohesion. ${ }^{76}$ Ibn al-Qayyim noted that reflective recitation of the Qur'an is the crucial remedy in healing the heart. ${ }^{77}$ Faith in God's matchless forgiveness in all major and minor sins, commandments to not lose hope or despair (Qur'an, 39: 53) and repentance are among the spiritual application instilling sentiments of mercy, compassion, and love of God.

However, during treatment, it is important to consider what prompts thinking about substance and the necessary changes required for impulse management. The Qur'an encourages reflective thinking and directing one's sights to surrounding physical signs (Qur'an, 80: 24; 86: 5). Introducing "mindfulness therapy" helps identify negative and detrimental thoughts by way of redirecting the addict's thinking energy to building a positive and purposive meaning of life. This step seeks to nurture faith-based thinking through contemplating divine visual manifestations, written signs, the divine order that connects all things, the wisdom found in creation, the purpose of human life, and miraculous human creation endowed with unique abilities and skills. All this helps revive and animate the pure and innate human nature (fitrah), a consciousness of the order, balance, and purposiveness of life. What is meant by written signs here, is the meanings found in Quranic texts which have much to offer in the pursuit of healing. The practice of repeatedly reciting specific verses and listening is expected to help refine the addict's character of negative habits. Dhahabì (d.1348 AD) considers the use of listening to music (sama) as one of the foremost tools of spiritual healing and strongly recommends sounds of the Qur'an, songs of virtuous content, and melodious voices with no interference because it generates tranquility in the self. ${ }^{78}$

Addiction recovery programs consist of conversations, dialogue, focus group discussions, debate, and storytelling as a medium to influence addicts. These mediums promote inquisitive thinking and attention to questions and answers pertaining to God, man, life, the world, and

${ }^{76}$ Bensaid, "Crossroads Between Muslim Spirituality and Environmental Sustainability", p. 67.

77 Al-Imam Ibn Qayyim al-Jawziyyah, Miftah Dar Al-Sa'adah, vol. 2, ed. by 'Abderahman bin Hassan bin Qa'id (Jeddah: Dar 'Alam al-Fawaid, 2011), p. 536.

${ }_{78}$ Dhahabī, al-Tibb al-Nabawi, p. 312. 
hereafter. Such sessions may take place as sessions scheduled daily throughout the treatment period. This is followed up by systematic assessment, symptom analysis, an assessable spiritual plan of action, implementation of the spiritual treatment, and consistent support for relapse prevention.

In the following, we draw on Nursi's noteworthy methods for psychological challenges and distress which may be integrated into psychotherapy in dealing with devout Muslim clients. Nursi's idea on the treatment of addicts is stated as follows: "The only way to save the dissipated from their vice is to show them the present pain in their pleasure and to defeat their emotions...The only way of saving them... from the danger of succumbing to it is by showing them the helllike torments and pains they suffer even in this world." ${ }^{79}$ For Nursi, 'dissipation' is the involvement in Islamically prohibited acts or what occurs "out of control". Nursi enumerated three characteristics of the evil-commanding psyche. First, prefers an ounce of immediate, present pleasure to immense and postponed, hidden pleasure. ${ }^{80}$ Second, humans shrinks at the fear of an immediate slap more than at a year's torment in the future, ${ }^{81}$ and third, blind to the consequences of things. ${ }^{82}$

Pain is a broad concept which encompasses several emotional states such as guilt, anger, anxiety, shame, and sadness. To overcome pain, Nursi proposes the spiritual defense or coping strategies of "Pain inside Pleasure" (PiP)" and "Hell-like Torments" (HiT). For Nursi, these interrelated methods can be effective with Muslim religious individuals suffering from psychological difficulties. But how does psychological conflict originate in Nursi's view and how do his concepts of PiP and HiT add to and complement Abu-Raiya's conceptualizations. ${ }^{83}$ According to Abu-Raiya, Nursi's description of the evil-commanding psyche resembles

${ }^{79}$ Bediuzzaman Said Nursi, The Flashes, 5th edition, trans. by Sukran Vahide (Istanbul: Sozler Publications, 1996), p. 640.

${ }^{80}$ Ibid., p. 111.

${ }^{81}$ Ibid.

${ }^{82}$ Bediuzzaman Said Nursi, The Rays Collection, 5th edition, trans. by Sukran Vahide (Istanbul: Sozler Publications, 2002), p. 640.

${ }^{83}$ Hisham Abu-Raiya, "Working with Religious Muslim Clients: A Dynamic, Qura'nic-Based Model of Psychotherapy", Spirituality in Clinical Practice, vol. 2, no. 2 (2015), pp. 120-33. 
the Freudian id many respects; the most common underlying similarity being that its processes are unconscious. Emergence of desires, feelings, and thoughts are the work of the evil-commanding psyche and might lead one to violate religious teachings on drugs and alcohol consumption, abuse, envy, hatred, adultery and so forth. The conflict occurs between the whims of the evil-commanding psyche (i.e., the work of Satan) and prescriptions of religion (i.e., commandments of God). The result of this conflict is what Nursi calls 'pain' and Abu-Raiya refers to as 'anxiety'. In the latter's model, the psychological structure responsible for anxiety reduction or conflict resolving is the conscious and purposeful ingredient of the psyche-intellect.

Nursi's notions of PiP and HiT may be utilized in the context of drug treatment and recovery. According to Nursi, individuals need to fully realize the pain/anxiety related to whims of the evil-commanding psyche which prompts impulses for immediate and short-lived gratification. One effective means of demonstrating the pain inside pleasure is likening this to the torments an individual might suffer in Hell. The Qur'an describes the suffering of eternal endurance in Hell in an extremely sensory graphic manner, familiarity with such torments is often common amongst Muslim devotees.

\section{Spiritual Discipline}

Muslim spirituality seeks to synchronize the world of reality with that of the spirit by way of forging bridges established upon reform of the inward and outward self, community, and surroundings. This is made according to the Islamic objective of promoting an integrated approach to esoteric and exoteric realities, the mundane and transcendental, underlying deep motives and intentions with actions, the individual with community and nature, as well as the worship of God and service of humanity. ${ }^{84}$ Spiritual discipline is concerned with awakening the self and qualities of the soul, such as love, compassion, patience, tolerance, forgiveness, contentment, responsibility, peace, and harmony. ${ }^{85}$ Works of Islamic spirituality addressing addiction therapy often approach the matter

${ }^{84}$ Bensaid, "Crossroads Between Muslim Spirituality and Environmental Sustainability", p. 66.

${ }^{85}$ Farhat naz Rahman, "Spiritual Healing and Sufi Practices", Nova Journal of Sufism and Spirituality, vol. 2, no. 1 (2014), p. 2. 
using mixed methods, approaches, and strategies. The literature centers attention on self-evaluation of symptoms, self-purification, restoration of morals, reform of attitudes and habits, developing a love and fear from God, strengthening self-control, and resilience to consuming desires.

Under guidance, addicts are to train themselves in self-introspection to prevent or reduce impulsive and compulsive responses as well as to overcome addictive lifestyle habits. Regular worship duties, chores, and social contact provide regular opportunities for drugs abstention and more avenues for dependency. As part of engaging in a process of repentance, addicts begin to naturally experience regret, hope of forgiveness and renewed commitments for change. This includes acknowledging the abuse of substance as sinning on heightened level, renouncing all that relates to it, and committing to a renewed and pure lifestyle. As for craving sensations, the course of spiritual learning and practices may be useful in address some, if not most underlying values, motivations, and impulses shaping addictive behaviors. This is possible in view of the multi-dimensional nature of spirituality, which is set to affect the emotions, cognitive, and behavioral aspects of the addict's personality. Spirituality is inherently holistic and ties all aspects of treatment into higher meanings, purpose, and directions, to God. Its multidimensional nature seeks to effectuate deeper and holistic changes within the addict' rather than simply adhering to surface symptoms of addiction. Cook notes that the integration of spirituality into addiction recovery provides a holistic approach to addiction treatment as it addresses the psychological, emotional, physical, social, and spiritual aspects of individuals. ${ }^{86}$

Ibn al-Qayyim discusses the importance of spirituality in treating ailments as well as the need to assist patients in re-considering their state of spirituality and to improve them through various methods. One method is that of purposive conversation in which the physician works to reframe the meaning of sickness and enrich it with nuanced interpretations outside the conventional medical format. This approach provides the patient with courage and strength in enduring their ailment in addition to experiencing contentment and positivity regardless of the fatality or futility of their circumstance. Such results are often arrived at through reminding the patient of the trying nature of life. Most healing

${ }^{86}$ Cook, "Religion and Spirituality in Clinical Practice", pp. 42-50. 
is both spiritual and emotional; it involves trust in God, submission, subservience to Him, prayers and supplications, exercise of repentance, forgiveness, and compassion.

Badri's view holds that Muslim literature has been extraordinary successful in the treatment of alcohol addiction due to faith-based alternatives and rituals that block which are preventive to craving and dependency. ${ }^{87}$ The Qur'an's emphasis on practices of remembrance (dbikr) and prayer (salat) are believed to strengthen the devotee's resilience and immunity to abuse and all that may ensue (Qur'an, 29: 45). For example, Prayer restrains from all that is indecent, shameful, and evil (Qur'an, 29: 45) while fasting serves as a firm disciplinary measure for the self. The organic effect of rituals on individuals is expected to yield impact when meanings are thoroughly grasped, and they are performed in an authentic prophetic manner. Islamic rituals exist not to merely regulate behavior but also to generate reflection, tranquility and augment a momentum of change and reform. Those rituals are also in place to develop distinctive spiritual and social environments which foster feelings of peace, security, and positive interpersonal relations.

In generating feelings of 'dislike, regret, remorse, guilt, and selfreproach...' within the addict, the regularity of Islamic rituals provides sustainable spiritual and emotional refuge as well as generated hope, optimism, willpower to combat impulses, and offer "high potential moments" for self-awareness, meaningful change, and sincere repentance to take place. Experiences of congregational prayer, fasting during the month of Ramadan, and the journey of hajj also play a role in achieving the purposes of addiction recovery and regained health. These rituals however must be comprehended in their complete meanings and nature. Al-Ghazali explains this as the 'asrar', literally translated as secrets, or the inner meanings and intrinsic contents of fundamental Islamic rituals. Furthermore, addict begin to confront the innermost aspects of addiction with the gained moral support of unremitting spiritual preoccupations such as scheduled regular prayers, remembrance of God (dhikr), recitation of the Qur'an and seeking of God's forgiveness. This is in addition to strong recommendations to find motivation in undertaking simple

${ }^{87}$ Mālik Badrī, Hikmat al-Islam fi-Tahrim al-khamr: Dirasah Naqdiya Ijtima íyah (Beirut: al-Ma‘had al-'Ālamī lil-Fikr al-Islāmī, 2005), pp. 160-70. 
studies as well as engaging in recitations of remembrance, glorification and supplication found in authentic compilations (ma'thürit) or God's ninety nine names.

Muslim spirituality highly regards the need for and merit of ritual purity or cleanliness, which is inclusive of the heart, body, garments, vicinity and extends to consumption. This is in line with the Islamic view which endorses strict dietary codes and commands abstinence from all that is ritually impure. Muslims are commanded to maintain a meticulous level of cleanliness which includes consistently performing ablution, dressing in clean clothes, showering on Fridays, clipping nails, combing hair, and refraining from disturbing congregating worshipers or surrounding spaces with bad odors. In the context of such teachings and etiquette, addicts gain a heightened awareness around purity, hygiene, and the symbiotic nature of the bodily, spatial, and ultimate spiritual state. In that same context, Islam also stresses transformative social experiences through good companionship, migration (bijra), isolation, social interaction and community's spiritual gatherings or occasions. The journey to Makkah and Medina which involves a great deal of preparation, travel, historical retrospection, and the promise of absolute forgiveness, are such ideal opportunities for monumental inner change, spiritual cultivation, and recovery.

Experiences of attending compulsory or voluntary spiritual congregations, fasting, giving charity, journeying to holy cities, and visiting cemeteries are all recommended in strengthening the resolve to confront addiction and reformulate the entirety of one's life affairs. Arriving at a stage of spiritual guilt and longing for God's unconditional forgiveness is significant in helping addicts overcome the initial step of self-denial. In addition to this, redirected attention to the divine results in a reassessment of precedencies and by contrast, the poisonous and shallow nature of substance. The detrimental effects of addictive behavior on overall health and well-being instead become hindrances to newfound aspirations for spiritual contentment and eternal salvation. The Islamic tradition is replete with directions and support to engage in spiritual merits of devotional acts such as, voluntary fasting, breaking fast with others, feeding fasting people, visiting family, providing company to the ill, fostering orphans and the poor, caring for the elderly, attending funerals, and even washing 
the deceased. Each act or practice is supplemented by details of etiquette as well as heartening narrations or verses explicating the cosmic rewards, and in effect, drawing struggling individuals to find hope and fulfilment.

One strategy involves revisiting the concept of death and regained consciousness around the reported pleasures or torments of the grave. According to Muslim scholars, contemplating death prevents sinning, softens the hearts, diminishes fascination with the fleeting pleasures of life, and strengthens resilience in the face of calamities and the hardships of life. ${ }^{88}$ The outcome of such thinking generates resolve to commence in detoxification and maintain their continuity, this not only plays into a cognitive reform but also supports relapse prevention. Many early Muslim sources can be applied in the design of funeral and cemetery visit programs. The works "dhiker al-mawt" (remembrance of death) by Ibn Abu al-Dunya (d. 894) and "tadhkirat bi Abwal al-mawt" (remembrance of the states of dead) by Qurtubi (d. 1273) are original sources in the field which explicate the Islamic view of death, which unlike conventional approaches, does not shroud the reality in stigma and fear but rather offers a firm reminder for those seeking renewal.

Spiritual experience and engagements are valuable in addressing inner urge due to the permeating nature of spirituality and its effects on deep emotions, inner drives, orientation, and social interactions. Spiritual immersion allows addicts to cope with different urges, negative thoughts, and relapses. This is achieved through strategies of encouragement and warning (al-targhib wal-tarhib), study of the forbidden and enjoined, an awareness of what may lead to the forbidden, learning stories and experiences of pious people, interaction with like-minded individuals, serving others, and preoccupying oneself with various types of worship. Storytelling is one notorious strategy in generating spiritual commitment as it provides listeners with inspiration from past individuals who endured, with faith, the greatest trials of loss, destruction, and ostracism. The stories of prophets are numerous and represent a universal diegeses for human struggle. They include those of Prophet Zachariah who despaired at his wife's barrenness, Prophet Jacob who endured the loss of his son, Prophet Joseph's many tribulations which included his

${ }^{88}$ Muhammad ibn Ahmad al-Qurtubi, Al-Tadhkirah bi Abwal al-Mawta wa Umur al-Akbirah, vol. 1 (Riyadh: Dar Al-Minhaj, 2004), p. 133. 
wrongful imprisonment and the abandonment of his immediate family, and Prophet Jonah who found himself submerged in the depths of the ocean while hopelessly awaiting death in the belly of a whale. These are a few of innumerable stories inspiring patience and reminding that strength to overcome loss, grief, trial, and despair are not found within or in external outlets, but rather in a higher power.

Approaches in treating addicts should also capitalize on concepts of tawbah (forgiveness), ibkla (predominant permittance of all things), khushu' (humility) and khulu' (veneration) in adopting a middle way between encouragement and warning, as expressed in the works of Mundhiri. Preachers and spiritual guides should thoughtfully deliver their spiritual context within the parameters of fear of and hope in God, and the lawful and unlawful. Rotated preaching is one valuable method practice by the Tablighi Jamaat which gives most if not all the members the chance to roleplay preaching the teachings of Faza'il al-A'mal (Merits of Good deed). Here there is no hierarchy of pious and sinner, all are provided with access to teachings and their shortcomings do not hinder their right to take a place amongst those calling to a good and pure life. The addict is therefore not humiliated or made to feel less worthy of spirituality. Ibn al-Qayyim states:

"You should know that healing and purifying (riyadah) of the soul is effective when practiced with care and thoughtfulness (talassuf) and when following gradual steps that allows for moving from spiritual state to another. It should not be dealt with roughly. The proper way is to mix hope use of hope and warning. Good friendship, avoiding bad people, study of the Qur'an and reflection on events (akbbar), exposing thought to the bless of paradise and sufferance of the hell, reading the biographies of wise and ascetics... are helpful acts" ${ }^{89}$

Visual art is also a viable spiritual therapy for addicts. In our context of discussion, it involves studying calligraphy, drawing, or painting of religious and spiritual themes. The ninety-nine names of God for example are attributes of humanly incomprehensible mercy, forgiveness, wisdom, love, justice, and numerous other contentment inducing descriptions. Images of the mosques or the Ka'ba often contain aesthetically pleasing

${ }^{89}$ Abū al-Faraj 'Abd al-Rahmān ibn 'Alī Ibn al-Jawzīi, al-Ṭibb al-Rüh̆ānī, ed. by Abū Hājar Muhammad al-Sa îd ibn Basyūnī Zaghlūl (Cairo: Maktabat al-Thaqāfah al-Dīnìyah, 1986), p. 132. 
geometric patterns and designs for Muslims as they are based in themes of oneness, unity and drawing the eyes higher, into domes and arches, or presumably into heaven. Writing on spiritual themes is also recommended as it allows addicts to not only verbalize repressed struggles, but also direct their writing to visions of a balanced future and plans to cope through spirituality. In building up physical strength, the Prophetic tradition urges Muslims to engage in specific purposive, useful and entertaining sports such as horseback riding, archery, and swimming, each of which contains its own character-building merits (trust and coordination in horseback riding, focus and patience in archery, and conscientiousness in swimming).

\section{Support and Integration}

In a study of thirty successful cases of alcohol addiction recovery, Badri found that the majority was reinforced through faith (spirituality). He discussed positive (reward) and negative (punishment) spiritual selfreinforcement in the context of addiction treatment. These precepts alone, however, are insufficient. Addicts should also benefit from the spiritual merits of community. The congregation prayer for instance, nurtures sustained community feelings which assure necessary minimum levels of community belonging, support, and opportunities for change. The merits of Islamic fellowship and spiritually like-minded circles allow for shared common spiritual practices and provide the necessary support for united efforts in overcoming shared weaknesses and shortcomings. These may potentially prevent addiction relapses while strengthening the very framework of emotional and social support, spiritual motivation, modelling, and retention. At this stage, addicts should not be driven to any radical or permanent isolation or disconnection from community life and business. Rather they should be encouraged to continue to function within society and make all possible contributions where possible.

Islam is communal and does not opt for exclusion or the neglect of one's duties towards themselves, their families and community. In this context of discussion, spiritual discipline, and support, assist the addict in regaining spiritual and moral balance all while demanding that they are occupied with functioning positively and responsibly. Such a vision, however, requires calculated friendship network building, and for this one is to invest with well in inter-personal relations focused on good 
character. In a chapter entitled "Knowing of man's imperfections", Razi proposed the company of those who are trustworthy, knowledgeable, wise, and in possession of healing skills. ${ }^{90}$ Islamic literature is rich with works on good companionship and friendship, some examples include al Ghazali's "Adab al-Subbah wal mu'asharab" and "Adab al-"ushrah waldhikr al-subba wal-ukbumwab" by Abu al-Barakat Badr al-Din Muhammad al-Ghaziy (d. 1576).

Supportive family ties, neighbors, friends, community spiritual networks and circles are crucial to the effective treatment and therapy of addicts. Within Muslim societies in general, there exists a largely spiritual continuum expressed in the normative acknowledgment of family upbringing, core values, parenting styles, and dynamics. This makes the family play a critical role as a channel of spiritual support via emotional and social support, healthy and effective communication, cultivation, and solidification of values and attitudes in daily practice. In collaboration with spiritual plans and programs being conducted for addicts, families can develop and supplement their roles as a informed, proactive and safe conduits between addicts and society by facilitating the addicts direct involvement in day to day planning and coordination, social visits, communication.

The challenge of addiction concerns the entire present and future of the encircling community' health, wellbeing, and resources. In line with the Islamic tradition, addiction prevention and treatment are viewed as a collective socio-moral and spiritual obligation. This calls for Muslim jurists to prioritize the channeling of Zakat, charity and waqfs for the development of specialized therapy centers, rehabilitation program and activity implementation and supporting micro-financing and entrepreneurship coaching for disadvantaged addicts and their families. Having said that, addicts should, according to subjective judgment, be treated and approached not as passive or hopeless agents, but rather, as individuals with freedom, independence, willpower, and resolve, who in the process of proper interactive treatment and care, are able to significantly contribute to their societies and may outperform in the quality of their contributions.

${ }^{90}$ Ar-Razi, At-Thibb Ar-Rubani, pp. 51-2. 


\section{F. Concluding Remarks}

This study sought to explore and assess the theoretical and empirical literature on Islamic spirituality and its relationship with addiction and addiction treatment. Moreover, this paper addressed spirituality's potential strengths as a source of meaning-making, discipline, support, and reintegration in developing long term methods and strategies for spirituality-based addiction programs and treatments. Notedly, the spiritual approach to addressing addiction outlined in this paper entails various benefits and prospective avenues in need of further study. Foremost among these is the socio-economic leniency granted to addicts within the Islamic spiritual framework, which is affordable and does not entail any financial burden on the shoulders of addicts who are often left to fend at the mercy of their finances. The approach of a spiritual communal involvement, interaction and engagement is also found to be simple, open, accessible, inclusive, and enriching. The diversity found within spiritual theory and practice positions this ecological framework to be advantageous to new addiction treatment, rehabilitation, and community reintegration practices which are holistic. 
An Islamic Spiritual Alternative to Addiction Treatment and Recovery

\section{BIBLIOGRAPHY}

Abu-Raiya, Hisham, "Working with Religious Muslim Clients: A Dynamic, Qura'nic-Based Model of Psychotherapy", Spirituality in Clinical Practice, vol. 2, no. 2, 2015, pp. 120-33 [https://doi.org/10.1037/ scp0000068].

Ah, Peterman et al., "Measuring Spiritual Well-being in People with Cancer: the Functional Assessment of Chronic Illness TherapySpiritual Well-being Scale (FACIT-Sp)", Annals of Behavioral Medicine: a Publication of the Society of Behavioral Medicine, vol. 24, no. 1, 2002 [https://doi.org/10.1207/S15324796ABM2401_06].

Ali, Mansur, "Perspectives on Drug Addiction in Islamic History and Theology”, Religions, vol. 5, no. 3, 2014, pp. 912-28 [https://doi. $\operatorname{org} / 10.3390 /$ rel5030912].

Amin, M.Z.M. Zohdi et al., "A Literature Review of Spiritual Psychotherapy Using Quran Recitation in the Treatment of Drug Addiction", Advanced Science Letters, vol. 23, no. 5, 2017, pp. 4865-8 [https://doi.org/10.1166/asl.2017.8929].

Angres, Daniel H. and Kathy Bettinardi-Angres, "The Disease of Addiction: Origins, Treatment, and Recovery", Disease-a-Month: DM, vol. 54, no. 10, 2008, pp. 696-721 [https://doi.org/10.1016/j. disamonth.2008.07.002].

Arfken, Cynthia.L. and Sameera Ahmed, "Ten Years of Substance use Research in Muslim Populations: Where do we go from here?”, Journal of Muslim Mental Health, vol. 10, no. 1, 2016.

Ar-Razi, Fakhruddin, At-Thibb Ar-Ruhani, Cairo: Maktabat al-Nahda al-Misriyya, 1978.

Assanangkornchai, Sawitri, Katherine M. Conigrave, and John B. Saunders, "Religious Beliefs and Practice, and Alcohol Use in Thai Men", Alcohol and Alcoholism, vol. 37, no. 2, 2002, pp. 193-7 [https:// doi.org/10.1093/alcalc/37.2.193].

Badr, Lina Kurdahi, Asma Taha, and Vivien Dee, "Substance Abuse in Middle Eastern Adolescents Living in Two Different Countries: Spiritual, Cultural, Family and Personal Factors", Journal of Religion and Health, vol. 53, no. 4, 2014, pp. 1060-74 [https://doi. 
Benaouda Bensaid et al.

org/10.1007/s10943-013-9694-1].

Badrī, Mālik, Hikmat al-Islam fi-Tahrim al-Khamr: Dirasah Naqdiya Ijtima ‘ijah, Beirut: al-Ma'had al-'Ālamī lil-Fikr al-Islāmī, 2005.

Bahorik, Amber L. et al., "Alcohol, Cannabis, and Opioid Use Disorders, and Disease Burden in an Integrated Healthcare System", Journal of Addiction Medicine, vol. 11, no. 1, 2017, pp. 3-9 [https://doi. org/10.1097/ADM.0000000000000260].

Bathish, Ramez et al., "Is it me or should my friends take the credit?' The Role of Social Networks and Social Identity in Recovery from Addiction", Journal of Applied Social Psychology, vol. 47, no. 1, 2017, pp. 35-46 [https://doi.org/10.1111/jasp.12420].

Bensaid, Benaouda, "Crossroads Between Muslim Spirituality and Environmental Sustainability", Journal of Al-Tamaddun, vol. 13, no. 1, 2018, pp. 65-81 [https://doi.org/10.22452/JAT.vol13no1.7].

Berzinski, Carmen, "Recovery Mentorship Programs and Recovery from Addiction", Master Thesis, Minnesota: St. Catherine University, 2012.

Best, David W. et al., "Breaking the Habit: A Retrospective Analysis of Desistance Factors Among Formerly Problematic Heroin Users", Drug and Alcohol Review, vol. 27, no. 6, 2008, pp. 619-24 [https:// doi.org/10.1080/09595230802392808].

Betty Jarusiewicz PhD, CADC, "Spirituality and Addiction", Alcoholism Treatment Quarterly, vol. 18, no. 4, 2000, pp. 99-109 [https://doi. org/10.1300/J020v18n04_08].

Borders, Tyrone F. and Brenda M. Booth, "Stimulant Use Trajectories and the Longitudinal Risk of Heavy Drinking: Findings from a Rural Population-based Study', Addictive Behaviors, vol. 37, no. 3, 2012, pp. 269-72 [https://doi.org/10.1016/j.addbeh.2011.11.003].

Brohi, Allahbakhsh K., "The Spiritual Significance of the Qur'an”, in Islamic Spirituality: Foundations, ed. by Seyyed Hossein Nasr, New York: Routledge, 2013.

al-Bukhari, Imam Muhammad bin Ismail bin al-Mughirah, Sabih AlBukhari, Beirut: Dar Ibn Kathir, 2002.

Cook, Christopher C.H., "Religion and Spirituality in Clinical Practice", 
An Islamic Spiritual Alternative to Addiction Treatment and Recovery

BJPsych Advances, vol. 21, no. 1, 2015, pp. 42-50 [https://doi. org/10.1192/apt.bp.114.013276].

Dermatis, Helen and Marc Galanter, "The Role of Twelve-Step-Related Spirituality in Addiction Recovery", Journal of Religion and Health, vol. 55, no. 2, 2016, pp. 510-21 [https://doi.org/10.1007/s10943015-0019-4].

Dhahabī, Muḥammad ibn Aḥmad, al-Ṭibb al-Nabawì, 3rd edition, ed. by Ahmad Rif'at al-Badrawi, Beirut: Dar Ihya al-'Ulum, 1990.

Duckworth, Angela Lee, Tracy A. Steen, and Martin E.P. Seligman, "Positive Psychology in Clinical Practice", Annual Review of Clinical Psychology, vol. 1, 2005, pp. 629-51 [https://doi.org/10.1146/ annurev.clinpsy.1.102803.144154].

Edlund, Mark J. et al., "Risks for Opioid Abuse and Dependence among Recipients of Chronic Opioid Therapy: Results from the TROUP Study", Drug and Alcohol Dependence, vol. 112, nos. 1-2, 2010, pp. 90-8 [https://doi.org/10.1016/j.drugalcdep.2010.05.017].

El-Guebaly, Nady, "The Meanings of Recovery from Addiction: Evolution and Promises", Journal of Addiction Medicine, vol. 6, no. 1, 2012, pp. 1-9 [https://doi.org/10.1097/ADM.0b013e31823ae540].

Fatayer, Jawad, "Addiction Types: A Clinical Sociology Perspective", Journal of Applied Social Science, vol. 2, no. 1, 2008, pp. 88-93 [https:// doi.org/10.1177/193672440800200107].

Gedge, Elisabeth and Deirdre Querney, "The Silent Dimension: Speaking of Spirituality in Addictions Treatment", Journal of Social Work Values and Ethics, vol. 11, no. 2, 2014, p. 11.

Ghobary Bonab, Bagher; Miner, "Attachment to God in Islamic Spirituality", Journal of Muslim Mental Health, vol. 7, no. 2, 2013 [https://doi.org/10.3998/jmmh.10381607.0007.205].

Haber, Jon Randolph, Laura B. Koenig, and Theodore Jacob, "Alcoholism, Personality, and Religion/Spirituality: an Integrative Review", Current Drug Abuse Reviews, vol. 4, no. 4, 2011, pp. 250-60 [https://doi. org/10.2174/1874473711104040250].

Haddad, Linda et al., "Knowledge of Substance Abuse Among High School Students in Jordan", Journal of Transcultural Nursing, vol. 21, no. 
Benaouda Bensaid et al.

2, 2010, pp. 143-50 [https://doi.org/10.1177/1043659609357632]. Hai, Audrey Hang et al., "The Efficacy of Spiritual/Religious Interventions for Substance use Problems: A Systematic Review and Meta-Analysis of Randomized Controlled Trials", Drug and Alcohol Dependence, vol. 202, 2019, pp. 134-48 [https://doi.org/10.1016/j. drugalcdep.2019.04.045].

Humphreys, Keith and Rudolf H. Moos, "Encouraging Post-treatment Self-help Group Involvement to Reduce Demand for Continuing Care Services: Two-year Clinical and Utilization Outcomes", Alcoholism, Clinical and Experimental Research, vol. 31, no. 1, 2007, pp. 64-8 [https://doi.org/10.1111/j.1530-0277.2006.00273.x].

Ibn al-Jawzī, Abū al-Faraj 'Abd al-Raḥmān ibn 'Alī, al-Ṭibb al-Rūḥ̄inì, ed. by Abū Hājar Muḥammad al-Sa'īd ibn Basyūnī Zaghlūl, Cairo: Maktabat al-Thaqāfah al-Dīnīyah, 1986.

Jason, Leonard A. et al., "Communal Housing Settings Enhance Substance Abuse Recovery", American Journal of Public Health, vol. 96, no. 10, 2006, pp. 1727-9 [https://doi.org/10.2105/AJPH.2005.070839].

Jason, Leonard A. and Joseph R. Ferrari, "Oxford House Recovery Homes: Characteristics and Effectiveness", Psychological services, vol. 7, no. 2, 2010, pp. 92-102 [https://doi.org/10.1037/a0017932].

al-Jawziyyah, Al-Imam Ibn Qayyim, Kitab Ar-Ruh, vol. 2, ed. by Muhammad Ajmal Ayub al-Islahi, Jeddah: Dar 'Alam al-Fawa'id, 2011.

----, Miftah Dar Al-Sa'adah, vol. 2, ed. by 'Abderahman bin Hassan bin Qa'id, Jeddah: Dar'Alam al-Fawaid, 2011.

Jf, Kelly, Yeterian J, and Myers Mg, "Treatment Staff Referrals, Participation Expectations, and Perceived Benefits and Barriers to Adolescent involvement in 12-Step Groups", Alcoholism Treatment Quarterly, vol. 26, no. 4, 2008 [https://doi.org/10.1080/07347320802347053].

Johnson, Thomas J., Virgil L. Sheets, and Jean L. Kristeller, "Identifying Mediators of the Relationship between Religiousness/Spirituality and Alcohol use", Journal of Studies on Alcohol and Drugs, vol. 69, no. 1, 2008, pp. 160-70 [https://doi.org/10.15288/jsad.2008.69.160]. Jordan, Kevin D. et al., "An Interpersonal Approach to Religiousness 
An Islamic Spiritual Alternative to Addiction Treatment and Recovery

and Spirituality: Implications for Health and Well-being", Journal of Personality, vol. 82, no. 5, 2014, pp. 418-31 [https://doi.org/10.1111/ jopy.12072].

Kaskutas, Lee Ann et al., "Effectiveness of Making Alcoholics Anonymous Easier: a Group Format 12-step Facilitation Approach", Journal of Substance Abuse Treatment, vol. 37, no. 3, 2009, pp. 228-39 [https://doi.org/10.1016/j.jsat.2009.01.004].

Kaye, Sharlene et al., "Methamphetamine and Cardiovascular Pathology: A Review of the Evidence", Addiction, vol. 102, no. 8, 2007, pp. 1204-11 [https://doi.org/10.1111/j.1360-0443.2007.01874.x].

Kelly, John F. et al., "Spirituality in Recovery: A Lagged Mediational Analysis of Alcoholics Anonymous' Principal Theoretical Mechanism of Behavior Change", Alcoholism, Clinical and Experimental Research, vol. 35, no. 3, 2011, pp. 454-63 [https://doi.org/10.1111/ j.1530-0277.2010.01362.x].

Koenig, Harold, Dana King, and Verna B. Carson, Handbook of Religion and Health, New York: Elsevier Science \& Technology, 1998.

Longabaugh, Richard et al., "Network Support as a Prognostic Indicator of Drinking Outcomes: the Combine Study', Journal of Studies on Alcohol and Drugs, vol. 71, no. 6, 2010, pp. 837-46 [https://doi. org/10.15288/jsad.2010.71.837].

MA, William L. White, "Recovery: Its History and Renaissance as an Organizing Construct Concerning Alcohol and Other Drug Problems", Alcoholism Treatment Quarterly, vol. 23, no. 1, 2005, pp. 3-15 [https://doi.org/10.1300/J020v23n01_02].

Machouche, Salah ben Tahar, Bensaid Benaouda, and Fadila Grine, "Positive Thinking: An Islamic Perspective", Al-Shajarah: Journal of the International Institute of Islamic Thought and Civilization, vol. 17, no. 2, 2012.

Mathew, R.J. et al., "A Retrospective Study of the Concept of Spirituality as Understood by Recovering Individuals", Journal of Substance Abuse Treatment, vol. 13, no. 1, 1996, pp. 67-73 [https://doi. org/10.1016/0740-5472(95)02022-5].

McKellar, John, Eric Stewart, and Keith Humphreys, "Alcoholics 
Benaouda Bensaid et al.

Anonymous Involvement and Positive Alcohol-related Outcomes: Cause, Consequence, or just a Correlate? A Prospective 2-year Study of 2,319 Alcohol-dependent Men", Journal of Consulting and Clinical Psychology, vol. 71, no. 2, 2003, pp. 302-8 [https://doi. org/10.1037/0022-006x.71.2.302].

McMillen, C. et al., "Positive by-Products of the Struggle with Chemical Dependency", Journal of Substance Abuse Treatment, vol. 20, no. 1, 2001, pp. 69-79 [https://doi.org/10.1016/s0740-5472(00)00151-3].

Mee-Lee, David et al., Patient Placement Criteria for the Treatment of SubstanceRelated Disorders, Second Edition-Revised, Chevy Chase, Maryland: Amer Society of Addiction Medicine, 2001.

van der Meer Sanchez, Zila and Solange Aparecida Nappo, "Religious Intervention and Recovery from Drug Addiction", Revista De Saude Publica, vol. 42, no. 2, 2008, pp. 265-72 [https://doi.org/10.1590/ s0034-89102008000200011].

Miller, Melissa L. and Stephen M. Saunders, "A Naturalistic Study of the Associations between Changes in Alcohol Problems, Spiritual Functioning, and Psychiatric Symptoms", Psychology of Addictive Behaviors: Journal of the Society of Psychologists in Addictive Behaviors, vol. 25, no. 3, 2011, pp. 455-61 [https://doi.org/10.1037/a0022224].

Mohamed, Mahmood Nazar et al., "Validation of Addiction Severity Index (5th edition) Bahasa Melayu Version (ASI-5-BM)", MOJ Addiction Medicine \& Therapy, vol. 4, no. 2, 2017, pp. 243-7 [https:// doi.org/10.15406/mojamt.2017.04.00075].

Mohamed, Mahmood Nazar and S. Marican, "Treatment and Rehabilitation of Substance Use Disorder: Significance of Islamic Input in Malaysia", International Journal of Human and Health Sciences (IJHHS), vol. 2, no. 4, 2018, pp. 209-16 [https://doi.org/10.31344/ ijhhs.v2i4.57].

Mohamed, Mahmood Nazar and Mohd Yunos Pathi Mohd, "The Role of Family in Preventing Drug Addiction", presented at the the 2nd Asian Seminar on Family Support Group Network, Colombo, Sri Lanka, 3 May 2004.

Muhammad, N.H.N. et al., "Prevention of Addiction Based on Islamic Ways", International Journal of Academic Research in Business and Social 
An Islamic Spiritual Alternative to Addiction Treatment and Recovery

Sciences, vol. 9, no. 2, 2019, pp. 865-75.

Murray, Krystina, "Muslim Drug and Alcohol Abuse Rehab", Addiction Center, 18 Sep 2020, https:/ / www.addictioncenter.com/treatment/ faith-based-drug-and-alcohol-rehab/muslim/, accessed 9 Oct 2020.

National Institute on Drug Abuse, Drugs, Brains, and Behavior: The Science of Addiction, Maryland: U.S. Department of Health and Human Services, 2007.

Nazar, Mohamed Mahmood and Marican Sabitha, 'Incorporating Islam in the Therapeutic Community Modality for Rehabilitation of Substance and Drug Users. A Malaysian Experience", International Journal of Human and Health Sciences (IJHHS), vol. 1, no. 1, 2017, pp. 7-17 [https://doi.org/10.31344/ijhhs.v1i1.2].

Nursi, Bediuzzaman Said, The Flashes, 5th edition, trans. by Sukran Vahide, Istanbul: Sozler Publications, 1996.

----, The Rays Collection, 5th edition, trans. by Sukran Vahide, Istanbul: Sozler Publications, 2002.

Piderman, Katherine M. et al., "Spirituality during Alcoholism Treatment and Continuous Abstinence for One Year", The International Journal of Psychiatry in Medicine, vol. 38, no. 4, 2008, pp. 391-406 [https:// doi.org/10.2190/PM.38.4.a].

al-Qurtubi, Muhammad ibn Ahmad, Al-Tadhkirah bi Abwal al-Mawta wa Umur al-Akhirah, vol. 1, Riyadh: Dar Al-Minhaj, 2004.

Rahman, Farhat naz, "Spiritual Healing and Sufi Practices”, Nova Journal of Sufism and Spirituality, vol. 2, no. 1, 2014, pp. 1-9.

Raiya, Hisham Abu et al., "A Psychological Measure of Islamic Religiousness: Development and Evidence for Reliability and Validity", The International Journal for the Psychology of Religion, vol. 18, no. 4, 2008, pp. 291-315 [https://doi.org/10.1080/10508610802229270].

Robinson, Elizabeth A.R. et al., "Six-Month Changes in Spirituality and Religiousness in Alcoholics Predict Drinking Outcomes at Nine Months", Journal of Studies on Alcohol and Drugs, vol. 72, no. 4, 2011, pp. 660-8 [https://doi.org/10.15288/jsad.2011.72.660].

Seghatoleslam, Tahereh et al., "Achieving a Spiritual Therapy Standard for Drug Dependency in Malaysia, from an Islamic Perspective: 
Benaouda Bensaid et al.

Brief Review Article", Iranian Journal of Public Health, vol. 44, no. 1, 2015, pp. 22-7.

Service Material from the General Service Office, "Estimated Worldwide A.A. Individual and Group Membership", Alcoholics Anonymous, https://www.aa.org/assets/en_us/aa-literature/smf-132-estimatesworldwide-aa-individual-and-group-membership, accessed 9 Jan 2021.

SESRIC \& ICYF-DC, State of Youth in OIC Member States 2017, Ankara: SESRIC-Statistical, Economic and Social Research and Training Centre for Islamic Countries, 2017.

Shīrāzì, Ṣadr al-Dīn Muḥammad ibn Ibrāhīm, Mafatih al-Ghayb, vol. 17, Beirut: Mu’assasat al-Tārīkh al-'Arabī lil-Ṭibā'ah wa-al-Nashr waal-Ṭawzī', 1981.

Sin, Nancy L. and Sonja Lyubomirsky, "Enhancing Well-Being and Alleviating Depressive Symptoms with Positive Psychology Interventions: A Practice-Friendly Meta-Analysis", Journal of Clinical Psychology, vol. 65, no. 5, 2009, pp. 467-87 [https:/ /doi.org/10.1002/ jclp.20593].

Tekke, Mustafa and P.J. Watson, "Supplication and the Muslim personality: Psychological nature and functions of prayer as interpreted by Said Nursi”, Mental Health, Religion \& Culture, vol. 20, no. 2, 2017, pp. 143-53 [https://doi.org/10.1080/13674676.2017.1328401].

Walton-Moss, Benita, Ellen M. Ray, and Kathleen Woodruff, "Relationship of Spirituality or Religion to Recovery from Substance Abuse: A Systematic Review", Journal of Addictions Nursing, vol. 24, no. 4, 2013, pp. 217-26; quiz 227-8 [https://doi.org/10.1097/ JAN.0000000000000001].

White, William L., "Addiction Recovery: Its Definition and Conceptual Boundaries", Journal of Substance Abuse Treatment, vol. 33, no. 3, 2007, pp. 229-41 [https://doi.org/10.1016/j.jsat.2007.04.015]. 